уДК 340

DOI https://doi.org/10.32849/2663-5313/2019.12.49

\title{
Терезія Попович,
}

канд. юрид. наук, дочент,

доцент кафедри теорії та історії держави і права

ДВНЗ «Ужгородський начіональний університет»

Андрій Шаварин,

аспірант кафедри теорії та історї держави і права

ДВНЗ «Ужгородський начіональний університет»

\section{СУТНICНЕ НАПОВНЕННЯ ЧЕТВЕРТОГО ПОКОЛІННЯ ПРАВ ЛЮДИНИ}

У статті проаналізовано сутнісне наповнення такого правового та сочіального феномену як четверте покоління прав людини. Зокрема, під четвертим поколінням прав людини розуміють комплекс прав, що сформувалися на зламі XX - ХХІ століть та виникли у результаті науковотехнічного прогресу, відкриттів у медицині, біології, генетиці, космічній сфері тощо, які ще повністю не визнані міжнародною спільнотою та потребують належного нормативного врегулювання. Досліджено, що двома основними групами четвертого покоління прав людини є соматичні права та права, що пов'язані з розвитком иифрових технологій, зокрема інтернету. До соматичних прав переважно відносять такі: право на смерть, право на трансплантачію, клонування, сексуальні права людини, репродуктивні права людини, право на зміну статі та ін. При ивому найбільш дискусійним та суперечливим із усіх прав людини четвертого покоління є право на клонування. Загалом науковиі виділяють два таких види клонування: репродуктивне, що означає створення нових живих організмів, в тому числі й людини, в штучних та лабораторних умовах, а також терапевтичне, що має на меті створення окремих органів та тканин тіла. У статті також висвітлюються особливості одного з основоположних та невід'ємних прав людини в епоху розвитку цифрових технологій - права вільного доступу до інтернету.

З урахуванням вищезазначеного зроблено висновок, що четверте покоління прав людини виступає надзвичайно важливим соціально-правовим явищем на сучасному етапі розвитку суспільства. Тендениіями останніх двох десятиліть є постійне збільшення наукових розвідок у даній сфері (при иьому спостерігаємо $і$ збільшення неоднозначних та дискусійних позичій як у вітчизняній, так $i$ зарубіжній правовій доктрині), систематизачія знань про права людини четвертого покоління та гостра критика деяких з них, особливо з морально-релігійних та етичних позицій. Це все засвідчує необхідність здійснення подальших доктринальних розробок щодо визначення сутнісного наповнення четвертого покоління прав людини в иілому та його окремих елементів зокрема.

Ключові слова: соматичні права, трансплантація, клонування, евтаназія, репродуктивні права, зміна статі, віртуальні права.

Постановка проблеми. Масштабні зміни в суспільному та науковому житті людства наприкінці $\mathrm{XX}$ та протягом перших двох десятиліть XXI століття зумовили виникнення четвертого покоління прав людини. Вчені-юристи дедалі частіше ведуть наукові дискусії стосовно того, які права слід відносити до четвертого покоління, а які ні, а також здійснюють спроби класифікації таких прав у рамках четвертого покоління прав людини. Відсутність єдиних наукових підходів щодо окресленої проблеми зумовлюють підвищену актуальність та цінність даного дослідження та визначають його безпосередню мету.

Права людини, що становлять четверте покоління, були предметами наукових досліджень таких вчених-науковців, як
О.С. Аврамова, А.Б. Венгеров, Ю.А. Дмитрієв, О.С. Жидкова, В.І. Крусс, М.А. Лаврик, О.Е. Радутний, Г.Б. Романовський, М.В. Савчин, К.О. Самокиш, А.П. Семітко, І.Я. Сенюта, В.Ю. Стеценко, С.Г. Стеценко та ін.

Мета статті полягає у розкритті змісту концепції четвертого покоління прав людини на основі аналізу особливостей окремих категорій цих прав.

Виклад основного матеріалу. Найбільш популярною та визнаною у наш час є класифікація прав та свобод людини, зроблена чеським та французьким юристом Карелом Васаком, який поділив усі наявні на той час права і свободи людини та громадянина на 3 покоління [1, с. 28-29]. Теорія трьох поко- 
лінь прав людини з'явилась у результаті наукової систематизації прав людини в історичному ракурсі.

Проте на зламі XX - XXI століть почалися дискусії про становлення четвертого покоління прав людини, що пов'язане 3 науково-технічним прогресом, відкриттями в медицині, біології, генетиці, в космічній сфері.

Ще П.І. Новгородцев помічав, що «час від часу поняття повинні перевертатися, щоб могло розпочатися нове життя» [2]. Щось подібне, на нашу думку, можна сказати і про права людини на сучасному етапі, адже за останні два десятиліття перелік прав та свобод людини почав невпинно збільшуватись.

Так, наприклад, Г.Б. Романовський перелік прав четвертого покоління обмежує правами на самогубство і евтаназію. При цьому евтаназію та самогубство він розглядає як елементи права на смерть [3, с. 233]. На думку Ф.М. Рудинського, права четвертого покоління повинні захищати від загроз, пов'язаних з експериментами у сфері генетичної спадковості особи, тобто це такі права людини, які пов'язані з клонуванням та іншими відкриттями в галузі біології [4, с. 16]. Д.М. Шебаніц до прав четвертого покоління зараховує право на евтаназію, на зміну статті, на трансплантацію органів, на використання віртуальної інформації, право на клонування [5, с. 59]. А.Б. Венгеров називає четверте покоління правами людства. Це право на мир, на ядерну безпеку, космос, екологічні, інформаційні права тощо [6, с. 307].

Розглянувши й інші наукові підходи авторитетних вчених щодо досліджуваної проблеми, резюмуємо, що в рамках четвертого покоління прав людини можна виокремити принаймні дві такі групи: так звані соматичні права та права, пов'язані з розвитком цифрових технологій, у тому числі інтернету. Етимологічно поняття «соматичний» («соматичні») походить від грецького слова “soma” - «тіло». Тобто мова йде про групу прав людини, які пов’язані з ії можливістю самостійно розпоряджатися своїм тілом.

У контексті зазначеного варто згадати дослідження О.Е. Старовойтової, в якому вчена до соматичних прав відносить право на трансплантацію органів та тканин, на аборт, клонування, штучне репродукування, на розпорядження життям та власним тілом [7].

Наведемо також класифікацію російського правознавця М.О. Лаврика, який усі соматичні права поділяв на такі: 1) право на смерть (свобода людини свідомо та добровільно припинити своє життя обраним та доступним для неї способом (евтаназія або суїцид)); 2) права людини щодо її орга- нів і тканин (трансплантація, права донорів та реципієнтів); 3) сексуальні права людини (М.О. Лаврик розуміє під ними можливість шукати, одержувати і передавати інформацію, що стосується сексуальності (сексуальну освіту), вибору партнера, а також можливість вирішувати те, бути людині сексуально активною чи ні, самостійно вирішувати питання про добровільні сексуальні контакти, вступ до шлюбу, питання про легалізацію проституції, про обіг порнографічної продукції та правове регулювання становища сексуальних меншин); 4) репродуктивні права людини (позитивного характеру - штучне запліднення, негативного характеру - аборт, стерилізація, контрацепція); 5) право на зміну статі (з чоловічої на жіночу і з жіночої на чоловічу). Фактичною основою для визнання такого права є захворювання, що називається транссексуалізмом, а юридичною - право на охорону здоров'я.

Проте ні клонування, ні вживання наркотиків і психотропних речовин вчений не відносить до переліку соматичних прав, посилаючись або на пряму заборону чинного законодавства (у випадку клонування), або на криміналізацію супровідних діянь, пов'язаних із вживанням зазначених речовин. Питання про віртуальне моделювання також, на думку дослідника, наразі гостро не стоїть перед юридичним осмисленням [8, c. 22-23].

Розглянемо більш детально деякі з наведених категорій прав. Зокрема, під поняттям «евтаназія» (3 грец. «добра смерть») у сучасній біоетиці і медицині розуміють сприяння безболісному позбавленню життя безнадійно хворих. Головний аргумент, який висувають прихильники евтаназії, полягає в тому, що життя можна вважати благом і цінністю тільки за умови, коли в цілому задоволення i насолода переважають над стражданнями і випробуваннями. 3 огляду на концепцію прав людини людина має право розпоряджатися власним тілом і життям (отже, вона має право одноосібно вирішувати питання про евтаназію) [9, с. 184]. Так, у квітні 2002 року Нідерланди стали першою країною, яка легалізувала евтаназію. У Свропі деякі форми добровільної евтаназії також дозволені у Бельгії, Люксембурзі та частково Швейцарії. В Україні відповідно до ч. 4 ст. 281 Цивільного Кодексу забороняється задоволення прохання фізичної особи про припинення іï життя [10]. Що стосується питання необхідності визнання права на евтаназію, то як світова, так і вітчизняна спільнота не може дати однозначну відповідь на нього. Зміст цього права йде в розріз з морально-релігійними канонами, окрім 
цього, у разі його включення до правового статусу людини держава повинна визначити чіткий набір критеріїв застосування права на евтаназію, забезпечивши при цьому дієвий механізм контролю за належною процедурою їх дотримання.

Що стосується права на зміну статі, то зауважимо, що статтею 14 Свропейської конвенції з захисту прав людини та основоположних свобод 1950 року визначено: «Користування правами та свободами, визнаними в цій Конвенції, має бути забезпечене без дискримінації за будь-якою ознакою, наприклад, статі, раси, кольору шкіри, мови, релігіі, політичних чи інших переконань, національного чи соціального походження, належності до національних меншин, майнового стану, народження або за іншою ознакою» [11]. У контексті зазначеного доречно згадати рішення Суду Європейського Союзу від 27 квітня 2006 р., в якому він підтвердив, що дискримінація за ознакою перерозподілу статі повинна розглядатися як дискримінація за ознакою статі.

У будь-якому разі право на зміну статі повинно мати чітке і зрозуміле правове регулювання, однак все ж застерігаємо від правового облегшення у використанні цього права. Процедура зміни статі має проводитися тільки за медичними показаннями після ретельного обстеження та спостереження особи, щоб це не було миттєвим бажанням чи рішенням, прийнятим під впливом моди або життєвих обставин, короткочасного підліткового інтересу, способом самовираження чи самоствердження молодих людей у суспільстві. При цьому треба усвідомлювати, що зміна статі виражається у зміні не тільки фізичних даних, але і внутрішньої свідомості, світогляду, зміні соціальної ролі в суспільстві, сім'ї. Водночас змінюється і ставлення суспільства до особистості [12, с. 87].

В Україні зміна (корекція) статевої належності передбачена ст. 51 «Основ законодавства України про охорону здоров'я» 1992 року, у якій зазначається: «На прохання пацієнта відповідно до медико-біологічних і соціально-психологічних показань, які встановлюються центральним органом виконавчої влади, що забезпечує формування державної політики у сфері охорони здоров'я, йому може бути проведено шляхом медичного втручання в закладах охорони здоров'я зміну (корекцію) його статевої належності. Особі, якій було здійснено зміну статевої належності, видається медичне свідоцтво, на підставі якого надалі вирішується питання про відповідні зміни в її правовому статусі» [13].

Стосовно одностатевих шлюбів слід відзначити, що їх правовий статус значно змі- нився протягом останніх років. Очевидною $€$ тенденція до збільшення кількості держав, які легалізують право на одностатевий шлюб на національному законодавчому рівні. Сьогодні реєстрацію таких шлюбів узаконено у близько 30-ти країнах (з певними винятками). У деяких державах і територіях також дозволене одностатеве реєстроване партнерство, яке може передбачати такі ж права, як шлюб, або дещо обмежені порівняно зі шлюбом права. В Україні ж Сімейний кодекс чітко встановлює, що шлюбом є сімейний союз чоловіка та жінки, зареєстрований у органі державної реєстрації актів цивільного стану [14].

Як зазначає В.В. Речицький, підсумовуючи результати діяльності Робочої групи з прав людини Конституційної комісії України, що була спрямована на модернізацію II Розділу Конституції України, відбулася спроба виключити прив'язку шлюбу до формулювання «союз жінки та чоловіка». Проте ці зміни опинилися поки що за межами законопроєктної роботи [15, с. 84-86]. Це $є$ свідченням того, що на сучасному етапі Україна, як і решта пострадянських країн, ще морально, психологічно та ментально не готова закріплювати право людини на одностатевий шлюб на законодавчому рівні.

Що стосується права на штучне запліднення, то воно широко закріплене в цивільному законодавстві багатьох країн світу, в тому числі й в Україні. Зокрема, в нашій державі це право встановлене в п. 7. ст. 281 ЦК України, де визначається, що повнолітні жінка або чоловік мають право за медичними показаннями на проведення щодо них лікувальних програм допоміжних репродуктивних технологій згідно з порядком та умовами, встановленими законодавством [10]. Як зазначають С.Г. Стеценко, В.Ю. Стеценко та І.Я. Сенюта, поряд з очевидною медичною користю репродуктивних технологій виявилися проблеми морально-етичного і правового обгрунтування їх проведення [16, с. 387].

Моральна неоднозначність штучного запліднення полягає у тому, що під час цієі процедури створюеться декілька зайвих ембріонів, що не можуть бути імплантовані в організм майбутньої матері. Потім з організму жінки вилучаються ще декілька вже імплантованих ембріонів, що підлягають знищенню. Як слушно зауважує К.О. Самокиш, правове регулювання штучного запліднення має бути спрямованим на те, щоб стимулювати науковий прогрес на винайдення можливості створення під час запліднення in vitro лише одного ембріона [17, с. 288].

Відносно окремих прав четвертого покоління у сфері охорони здоров'я вже 
існує однозначна позиція Ради Свропи, СС та деяких міжнародних організацій. Наприклад, Хартія Європейського Союзу про основні права в п. 1 ст. 3 встановлює, що кожна людина має право на власну фізичну і душевну цілісність, а п. 2 конкретизує, що під час застосування досягнень медицини і біології необхідно особливо дотримуватися таких вимог: має бути добровільна і належним чином оформлена згода зацікавленої особи відповідно до правил, встановлених законом; повинна встановлюватися заборона на застосування євгеніки (практики покращення духовного і фізичного здоров'я людини), особливо їі частини, що має на меті селекцію людей; має встановлюватися заборона на використання людського тіла і його частин як джерела прибутку; має встановлюватися заборона на відтворення людини за допомогою клонування [18].

Справді, наразі найбільш дискусійним та суперечливим за своєю природою є право на клонування. Загалом науковці виділяють два види клонування: 1) репродуктивне, що означає створення нових живих організмів, в тому числі й людини, в штучних і лабораторних умовах; 2) терапевтичне, що має на меті створення окремих органів та тканин тіла [19, с. 73].

Ще одним актом, норми якого прямо встановлюють заборону клонування, $є$ Додатковий протокол про заборону клонування людини 1998 р. до Конвенції Ради Європи про захист прав і гідності людини щодо застосування біології та медицини 1997 р., який підписала більшість європейських країн. Так, його положеннями передбачено, що забороняється будь-яке втручання 3 метою створення людської істоти, генетично ідентичної іншій людській істоті, живій або померлій [20].

В Україні ще 14 грудня 2004 р. був прийнятий Закон «Про заборону репродуктивного клонування людини», згідно 3 яким в нашій державі заборонене репродуктивне клонування людини. Під клонуванням розуміється створення людини, яка генетично ідентична іншій живій або померлій людині, шляхом перенесення у залишену без ядра жіночу статеву клітину ядра соматичної клітини людини [21].

Що ж стосується другої групи прав людини, які чітко простежуються у складі четвертого покоління, а саме прав, пов'язаних з розвитком цифрових технологій, зокрема інтернету, то до них слід віднести такі: право на вільний доступ до інтернету, право на свободу слова в інтернеті, право на захист конфіденційності і персональних даних в інтернеті і онлайн-засобах інформації та інші так звані віртуальні права.
3 приводу права всіх людей на доступ до інтернету В.С. Татарова слушно зазначає, що ця необхідність зумовлена тим, що завдяки стрімким темпам розвитку інтернет сприяє революційним перетворенням в усіх сферах суспільного життя. Інтернет уже став потужним фактором соціального, освітнього і культурного прогресу. Він надає нові можливості як державним органам, так і звичайним громадянам і працівникам освіти, усуваючи бар'єри до створення і поширення матеріалів, пропонуючи загальний доступ до джерел цифрової інформації, кількість яких постійно збільшується. Однак інтернет містить також і певну частину потенційно неналежної, непристойної, образливої або протизаконної інформації і може іноді використовуватися як засіб злочинних дій. Хоча переваги інтернету набагато перебільшують його потенційні недоліки, ігнорувати ці проблеми не можна [22, с. 106].

Важливе значення для розуміння стандартів поширення інформації у Всесвітній мережі мають документи, прийняті ООН, Радою Європи, ОБСС та іншими міжнародними організаціями. Зокрема, в резолюції Ради ООН з прав людини «Про сприяння, захист та здійснення прав людини в інтернеті» від 5 липня 2012 року сформульований дуже важливий принцип, відповідно до якого «права, які людина має офлайн, мають однаковою мірою бути захищені онлайн, зокрема, це свобода вираження поглядів, яка застосовується незалежно від кордонів та щодо будь-яких обраних особою ЗМІ відповідно до статті 19 Загальної декларації прав людини та Міжнародного пакту про громадянські і політичні права». У цій резолюції визнається відкритий і глобальний характер інтернету і міститься заклик до держав сприяти та полегшувати доступ до мережі [23].

У практиці Європейського Суду з прав людини питання доступу до інтернету теж ставало предметом окремого розгляду. Зокрема, у рішенні за справою «Ахмет Юлдірім проти Туреччини» ССПЛ (ECHR Chamber judgment, case "Ahmet Yildirim v. Turkey”) (заява N. 3111/10) зафіксовано, що право безперешкодного доступу до інтернету слід також визнати. Суд зазначив, що превентивний захід мав протиправні наслідки і не може вважатись таким, що спрямований виключно на блокування доступу до спірного сайту, оскільки він спричинив загальне блокування усіх сайтів, які надавав хостинг "Google Sites". Водночас судовий контроль за блокуванням доступу до інтернет-сайтів не передбачав умов, достатніх для запобігання зловживанню, адже національне право не передбачає жодної гарантії для запобі- 
гання тому, аби захід з блокування, спрямований на конкретний сайт, не використовувався як засіб загального блокування» [24]. Більш детальний та грунтовний аналіз прав, пов'язаних з розвитком цифрових технологій, у тому числі інтернету, буде здійснено нами в наступних наукових працях.

\section{Висновки}

Концепція четвертого покоління прав людини є надзвичайно важливим соціокультурним та правовим феноменом на сучасному етапі розвитку суспільства. Дедалі більше вчених досліджує це явище, тому число фундаментальних напрацювань щодо окресленої проблеми невпинно зростає. При цьому спостерігаємо і збільшення неоднозначних та дискусійних позицій як у вітчизняній, так і зарубіжній правовій доктрині. Водночас окремі аспекти досліджуваної теми, на наш погляд, залишаються поза належною увагою. Зокрема, цікавим є питання щодо того, чи існування прав четвертого покоління дає нам підстави стверджувати про формування та розвиток нового покоління обов'язків людини. Відповідь на дане запитання спробуємо дати у подальших наукових розвідках.

у будь-якому разі беззаперечним залишається той факт, що визнання нових прав людини, розширення уже існуючого переліку - одна із тенденцій трансформаційного процесу правового статусу особи, що продиктована вимогами та потребами сьогодення. Однак мало лише визнати ці права, важливо створити та забезпечити ефективні й дієві механізми їх реалізації. А для цього слід визначитись, які ж нові можливості ми готові сприйняти як необхідні умови для нормального існування та розвитку людства чи його частини, а які є потенційно небезпечними та такими, що можуть завдати непоправної шкоди майбутнім поколінням та людській цивілізації у цілому.

\section{Список використаних джерел:}

1. Vasak Karel. A 30-year struggle; the sustained efforts to give force of law to the Universal Declaration of Human Rights. The UNESCO Courier: a window open on the world, Paris: United Nations Educational, Scientific, and Cultural Organization, November 1977. p. 28-29, p. 32. URL: https://unesdoc.unesco. org/ark:/48223/ pf0000048063 (дата звернення: $01.09 .2019)$.

2. Новгородцев П.И. О своеобразных элементах русской философии права. URL: http://iph. ras.ru/elib/Novgorodtsev_Rus_phil_prava.html (дата звернення: 01.09.2019).

3. Романовский Г.Б. К вопросу о праве на смерть как юридической основе легализации эвтаназии и самоубийства. Медичне право Укра- їни: проблеми управління та фінансування охорони здоров'я : матеріали III Всеукраїнської науково-практичної конференції з медичного права, м. Львів, 23-24 квітня 2009 р. / упор. Сенюта І.Я., Терешко Х.Я. Львів : ЛОБФ «Медицина і право», 2009. С. 232-234.

4. Рудинский Ф.М. Гражданские права человека: общетеоретические вопросы. Право и жизнь. 2000. № 31. С. $15-18$.

5. Шебаніц Д.М. Сучасна проблематика теоpiї «поколінь прав людини» в умовах європейської міждержавної інтеграції. Науковий вісник Ужгородського національного університету. Серія «Право». 2015. Вип. 31. Т.1. С. 57-61.

6. Венгеров А.Б. Теория государства и права : учебник для юридических вузов. Москва : Юриспруденция, 2000.478 с.

7. Старовойтова О.Э. Юридический механизм реализации и защиты соматических прав человека и гражданина в Российской Федерации: историкоправовой и теоретический анализ : дисс. ... докт. юрид. наук : 12.00.01. Санкт-Петербург, 2006. URL http://www.dslib.net/teoria-prava/juridicheskijmehanizm-realizacii-i-zawity-somaticheskih-pravcheloveka-i-grazhdanina.html (дата звернення: 20.09.2019).

8. Лаврик М.А. К теории соматических прав человека. Сибирский юридический вестник. 2005. № 3. C. 16-26.

9. Філософський енциклопедичний словник / B.I. Шинкарук (голова редколегії) та ін. Л.В. Озадовська, Н.П. Поліщук (наукові редактори) ; І.О. Покаржевська (художнє оформлення) Київ : Інститут філософії імені Григорія Сковороди НАН України ; Абрис, 2002. 742 с.

10. Цивільний кодекс України : Закон України від 16.01.2003 року № 435-IV. Відомості Верховної Ради України. 2003. № 40-44. Ст. 356.

11. Конвенція про захист прав людини та основоположних свобод від від 04.11.1950 року (дата набуття чинності для України - 17 липня 1997 року). Офіиійний вісник України. 1998. № 17. Ст. 270.

12. Струс Л.Б. Правове регулювання зміни статі. The Journal of Easterm European цаш / Журнал східноєвропейського права. 2019. № 67. C. $86-92$.

13. Основи законодавства України про охорону здоров'я : Закон України від 19.11.1992 року № 2801-XII. URL: https://zakon.rada.gov.ua/laws/ show/2801-12 (дата звернення: 30.10.2019).

14. Сімейний кодекс України : Закон України від 10.01.2002 року № 2947-III. Відомості Верховної Ради Украӥни. 2002. № 21-22. Ст. 135.

15. Речицький В.В. Права людини в Україні: критичний погляд на досягнуте. Право Украӥни. 2015. № 10. C. 79-86.

16. Стеценко С.Г., Стеценко В.Я., Сенюта І.Я Медичне право України / за заг. ред. С.Г. Стеценка. Київ : Всеукраїнська асоціація видавців «Правова єдність», 2008. 507 с.

17. Самокиш К.О. Правовий статус ембріона людини. Право України. 2012. № 7. С. 287-293. 
18. Хартія основних прав Європейського Союзу від 07.12.2000 року. URL: https:// zakon.rada.gov.ua/laws/show/994_524?lang=ru (дата звернення: 30.10.2019).

19. Триньова Я. Клонування людини - одна із сучасних кримінально-правових проблем. Юридична Україна. 2014. № 1. С. 72-79.

20. Додатковий протокол до Конвенції про захист прав і гідності людини щодо застосування досягнень біології та медицини, стосовно заборони клонування людських істот (ENS N 168) від 12.01.1998 p. URL: http://zakon5.rada.gov.ua/ laws/show/994 526 (дата звернення: 30.10.2019)

21. Про заборону репродуктивного клонування людини : Закон України від 14.12.2004 р.
URL: https://zakon.rada.gov.ua/laws/show/2231-15 (дата звернення: 05.11.2019).

22. Татарова В.С. Особливості правового регулювання мережі «Інтернет». Управління розвитком. 2014. № 6. С. 105-108.

23. Про сприяння, захист та здійснення прав людини в Інтернеті : Резолюція Ради ООН з прав людини від 5 липня 2012 року. URL: https://www.ppl. org.ua/bibliotech/mizhnarodni-ta-nacionalni-standartisvobodi-slova-v-interneti (дата звернення: 10.11.2019).

24. Рішення Європейського суду 3 прав людини від 18.12.2012 року. URL: https:// hudoc.echr.coe.int/app/conversion/pdf/?library= ECHR\&id=001-126863\&filename $=001-126863$. pdf\&TID=ihgdqbxnfi (дата звернення: 10.11.2019).

The article analyzes the essence of such a legal and social phenomenon as the fourth generation of human rights. In particular, the fourth generation of human rights refers to a set of rights that were formed at the turn of the 20th - 21st centuries and emerged as a result of scientific and technological progress, advances in medicine, biology, genetics, space sector, etc. that have not been fully recognized by the international community so far and require a regulatory framework.

The study found that there are two major groups of fourth generation human rights: somatic rights and the rights related to the development of digital technology, first of all, the Internet (digital rights). Somatic rights mainly include: the right to die, the right to organ transplants, cloning, sexual rights, reproductive rights, the right to gender change, etc. In this context, the most debatable and controversial of all human rights of the fourth generation is the right to clone. In general, scholars distinguish two types of cloning: reproductive, which means the creation of new living organisms, including humans, in artificial laboratory conditions, and therapeutic, aimed at creating individual organs and tissues of the body. The article also sheds light on the peculiarities of one of the fundamental and inalienable human rights in the digital age - the right to free Internet access.

In view of the above-mentioned, it has been concluded that the fourth generation of human rights is an extremely important socio-legal phenomenon at the present stage of the development of society. The tendencies in the last two decades have been a constant increase in research linked to this field (in this regard an increase of ambiguous and debatable issues both in the domestic and foreign legal doctrines is observed), the systematization of the knowledge about human rights of the fourth generation and sharp criticism of some of them, - especially, from a moral and religious as well as ethical points of view. This all highlights the need for further doctrinal developments concerning the determining of the essential content of the fourth generation of human rights in general, and its individual elements in particular.

Key words: somatic rights, transplantation, cloning, euthanasia, reproductive rights, gender change, virtual rights. 